\title{
Analysis of Uncoupling Protein 1 and $\beta 3$-adrenergic Receptor Single Nucleotide Polymorphisms in Saudi Population with Type 2 Diabetes Mellitus
}

\author{
Fathy M. Elfasakhany ${ }^{1,2 *}$, Abdulah M. Karawagh ${ }^{3}$, Shahid S. Siddiqui ${ }^{1,4}$, Magdi A. Eldamarawi ${ }^{5,6}$ \\ ${ }^{1}$ Department of Basic and Clinical Oral Sciences, Faculty of Dentistry, Umm Al Qura University, Makkah, Saudi Arabia; \\ ${ }^{2}$ Department of Medical Biochemistry, Faculty of Medicine, Tanta University, Tanta, Egypt; ${ }^{3}$ Department of Internal Medicine, \\ King Abdullah Medical Complex, Jeddah, Saudi Arabia; ${ }^{4}$ Department of Medicine, University of Chicago, Chicago, Illinois, USA; \\ ${ }^{5}$ Department of Medical Physiology, Faculty of Medicine, Tanta University, Tanta, Egypt; ${ }^{6}$ Department of Medical Physiology, \\ Faculty of Medicine, Tabuk University, Tabuk, Saudi Arabia
}

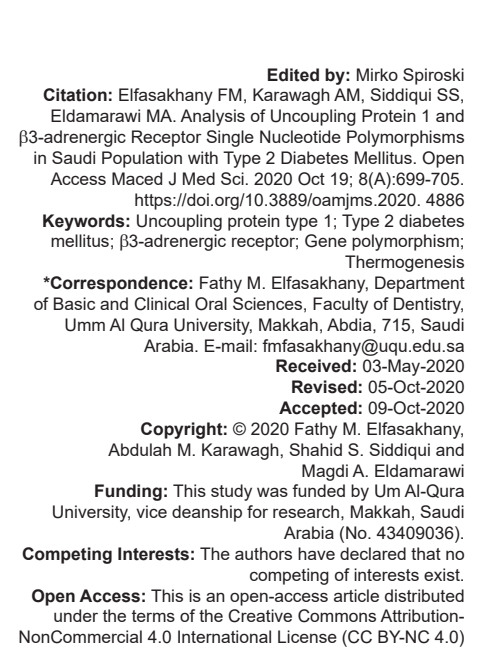

\section{Abstract}

BACKGROUND: Uncoupling proteins (UCP) and 33 -adrenergic receptor (ADRB3) gene polymorphism have been implicated in the susceptibility to type 2 diabetes mellitus (T2DM) but the results are inconsistent and inconclusive.

AIM: The aim was to investigate the relationship between -3826A/G (rs1800592) of UCP 1 and ADRB3 Trp64Arg (C/T) (rs4994) gene polymorphism and the incidence of T2DM among Saudis.

METHODS: Genotyping of both UCP1 and ADRB3 genes was carried out in 110 healthy controls and 108 unrelated Saudis with T2DM using polymerase chain reaction-based restriction fragment length polymorphism.

RESULTS: The genotype and allele frequencies of the UCP1 gene did not differ significantly between diabetic subjects and controls $(p>0.05)$. However, the CT genotype and the T allele of ADRB3 were higher in diabetic subjects compared with the controls while the CC genotype and $\mathrm{C}$ allele were higher in the controls relative to the diabetic subjects (Odds ratios [OR]: 7.85, 95\% confidence interval [Cl]: 4.23-14.59, p < 0.001 and OR: 7.434 95\% Cl: 4.026-13.39, $\mathrm{p}<0.001$, respectively).

CONCLUSION: The UCP1 -3826A/G polymorphism may not be associated with the susceptibility to T2DM among Saudis while T allele of ADRB3 may be related to the risk of T2DM, whereas the CC genotype and C allele may confer protection to T2DM.

\section{Introduction}

In recent years, lifestyle-related diseases including type 2 diabetes mellitus (T2DM), obesity, and coronary artery disease have become a serious problem [1]. These lifestyle-related diseases are thought to be related to both genetic and environmental factors [2]. Saudi-Arabian population is showing a steady increase in the prevalence of DM [3], [4]. DM is reported to be a potentially preventable disease if its risk factors are detected and lifestyle changes are implemented [5], 6], [7]. Among proteins that have a critical role in energy balance and metabolic regulation and in decreasing the mitochondrial production of reactive oxygen species, which are important mechanisms in the pathogenesis of obesity and/or T2DM, are the uncoupling proteins (UCPs) and Beta-3 adrenergic receptors [8], [9]. UCPs are transmembrane proteins which disrupt the proton gradient produced by oxidative phosphorylation by increasing the permeability of the inner mitochondrial membrane, allowing pumped protons into the intermembrane space to return to the mitochondrial matrix [8], [10], [11]. The UCP1 is mainly expressed in brown adipose tissue and acts as a proton transporter that uncouples oxidative reactions from ATP synthesis and energy consumption [12], [13]. Meanwhile, UCP1 acts in brown adipose tissue to generate heat by non-shivering thermogenesis which is the primary means of heat generation in human infants. Heat generation mediated by UCP1in brown fat uncouples the respiratory chain, leading to rapid substrate oxidation with a low rate of ATP production. Fatty acids activate UCP1 in the fat cell of brown adipose tissue while nucleotides inhibit it [11]. Fatty acids perform such activation through this cascade: Sympathetic nervous system (SNS) terminals release norepinephrine onto a Beta-3 adrenergic receptor on the plasma membrane. This activates adenylyl cyclase, which catalyzes the 
conversion of ATP to cyclic AMP (cAMP). cAMP activates protein kinase $A$, causing its active $C$ subunits to be freed from its regulatory $R$ subunits. Active protein kinase $A$, in turn, phosphorylates triacylglycerol lipase, thereby activating it. The lipase converts triacylglycerols into freefatty acids, which activate UCP1, overriding the inhibition caused by purine nucleotides (guanosine diphosphate and adenosine diphosphate) [14], [15], [16]. At the termination of thermogenesis, the mitochondria oxidize away the residual fatty acids, UCP1 inactivates and the cell resumes its normal energy-conserving mode. A summary of this signaling pathway is shown in a schematic form (Figure 1). The relationship between the polymorphism of the UCP1 gene and the physical or metabolic variables has been previously studied in diverse ethnic populations [8], [17], [18]. UCP1 gene polymorphism especially the $-3826 \mathrm{~A} / \mathrm{G}$ polymorphism in the promoter region has been investigated in several genetic studies which showed variable results. Some studies have shown that the $-3826 \mathrm{~A} / \mathrm{G}$ polymorphism is associated with obesity, T2DM, body mass index (BMI), and other features of metabolic syndrome while other studies did not find any association between this polymorphism and these conditions [8], [19]. Meanwhile, it was reported that $\beta$ 3-adrenergic receptors have a crucial role in thermogenesis and lipid tissue metabolism [20]. Mutation of the $\beta 3$-adrenergic receptor (ADRB3) gene at codon 64 [Trp64Arg (C/T) (rs4994)] has been reported in different ethnic populations and was found to be associated with an early onset of T2DM and
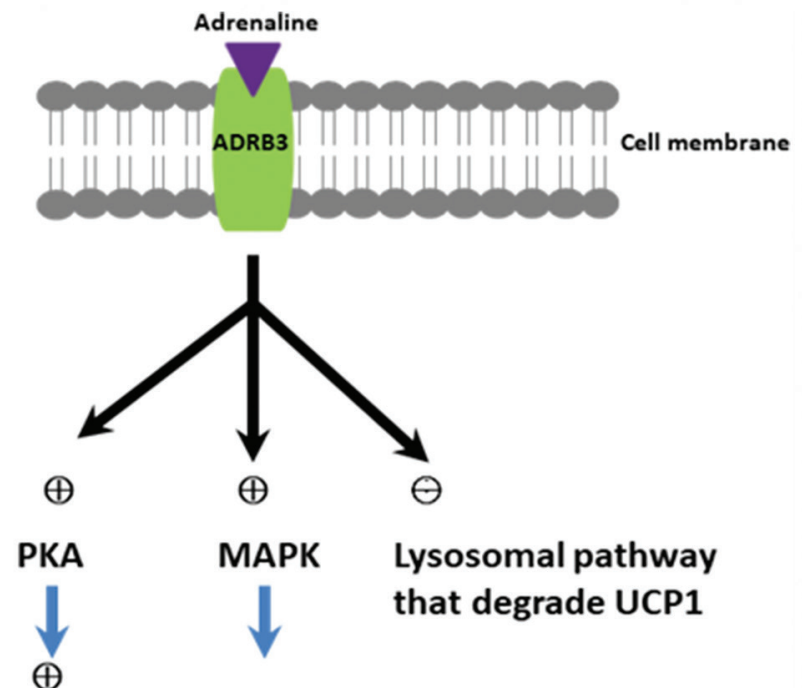

\section{Lipolysis Induction of UCP1}

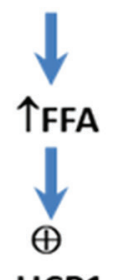

\section{UCP1}

Figure 1: Beta-3 adrenergic receptor stimulation activates UCP1. This is carried out - at least in part - through activation of protein kinase $A(P K A)$ and p38 mitogen-activated protein kinase (MAPK) pathway and inhibition of lysosomal pathways that degrade UCP1 an increased weight gain and insulin resistance in specific populations [21], [22], [23], [24], [25]. Interestingly, it has been reported that both UCP1 and ADRB3 polymorphisms act synergistically to lower the basal metabolic rate and to decrease SNS activity [26], [27], [28]. Herein, we aimed to investigate whether the ADRB3 Trp64Arg (C/T) and UCP1 -3826A/G polymorphisms are associated with the risk of T2DM among Saudi population in Makkah region. To the best of our knowledge, this is the first report to study the association of ADRB3 Trp64Arg (C/T) and UCP1 -3826A/G polymorphisms and T2DM among Saudi population.

\section{Materials and Methods}

\section{Study design and participants}

A total of two hundreds eighteen gender- and age-matched Saudi participants were selected for the study. Hundred eight unrelated Saudi patients with T2DM were randomly recruited from the health centers and the teaching dental hospital, Faculty of Dentistry, Umm Al Qura University, Makkah region, Saudi Arabia. The control subjects consist of hundred ten healthy individuals who either attended a routine health check at a general practice or at their place at work. The inclusion criteria to select controls were the absence of family history of T2DM among parents, brothers, sisters, and siblings. All subjects were nonsmokers and nonalcoholics. Patients with obesity, impaired renal function (diabetic nephropathy), and coronary artery disease were excluded. All subjects completed standard questionnaire and subjected to physical examination including basic data (name, age, gender, lifestyle [smoking, dietary intake, and physical activity], and anthropometric measures (height, weight, and $\mathrm{BMI}$ ). Height and weight were measured while wearing light weight clothing and without shoes. The BMI was calculated from the equation: $\mathrm{BMI}=$ Weight $(\mathrm{kg}) /$ height $\left(\mathrm{m}^{2}\right)$. Physical activity was assessed using physical activity questionnaire and the activity was divided into three levels (low, moderate, and high) (Table 1).

Table 1: Demographic and laboratory data for control subjects and patients with T2DM

\begin{tabular}{|c|c|c|c|}
\hline \multirow[t]{2}{*}{ Characteristics } & Control group & Patient group & \multirow[t]{2}{*}{$P$-value } \\
\hline & (110) & & \\
\hline Age (years) & $39.10 \pm 6.07$ & $41.2 \pm 6.88$ & NS \\
\hline Gender (M/F) & $67 / 43$ & $66 / 42$ & \\
\hline BMI $\left(\mathrm{kg} / \mathrm{m}^{2}\right)$ & $23.47 \pm 1.44$ & $23.61 \pm 1.23$ & NS \\
\hline FBS & $83.12 \pm 7.13$ & $159.19 \pm 28.98$ & $<0.001$ \\
\hline $\mathrm{HbA} 1 \mathrm{c}(\%)$ & $4.43 \pm 1.03$ & $7.23 \pm 1.61$ & $<0.05$ \\
\hline \multicolumn{4}{|c|}{ Dietary intake (Vegetable intake) (\%) } \\
\hline No or small & $76(69.09)$ & $83(76.85)$ & NS \\
\hline More & $34(30.91)$ & $25(23.15)$ & NS \\
\hline \multicolumn{4}{|c|}{ Physical activity (\%) } \\
\hline Low & $40(36.36)$ & $57(52.78)$ & $>0.05$ or NS \\
\hline Moderate & $22(20)$ & $32(29.63)$ & NS \\
\hline High & $48(43.64)$ & 19 (17.59) & $<0.001$ \\
\hline
\end{tabular}




\section{Ethics}

This study was approved by the Ethics Review Board of the Faculty of Dentistry, Umm Al Qura University, Makkah, Saudi Arabia. All participants signed written informed consent before participation in the study.

\section{Blood collection and biochemical procedures}

Venous blood samples were obtained from all subjects after overnight fasting and each sample was divided into two halves, one half for serum preparation and the other half was put in sterile K3EDTA (tripotassium ethylenediaminetetraacetic acid) coated tubes. The buffy coat white cells were used for DNA extraction. The samples were kept at $-20^{\circ} \mathrm{C}$ till the time of use. Fasting blood glucose (FBS) was determined using glucose oxidase method according to the manufacturer instructions (Human Diagnostics, Wiesbaden, Germany). $\mathrm{HbA}_{1 \mathrm{c}}$ was quantitatively determined using enzymatic $\mathrm{HbA}_{1 \mathrm{c}}$ assay kit according to the manufacturer instructions (Human Diagnostics, Wiesbaden, Germany).

\section{Genomic DNA extraction}

Peripheral blood leukocytes from the buffy coat of the anticoagulated blood were used for extraction of genomic DNA using DNA extraction kit (QIAamp DNA Blood Mini Kits, Qiagen, Hilden, Germany), according to the instructions of the manufacturer. Aliquots of genomic DNA were utilized for PCR amplification.

\section{UCP1 genotyping}

UCP1 -3826A/G polymorphism was determined using PCR-restriction fragment length polymorphism (RFLP) according to the method described previously [29]. The PCR was done in a final reaction volume of $20 \mu \mathrm{l}$ using the primers: 5'-CTTGGG TAGTGACAAAGTAT-3' as a forward primer and 5'CCAAAGGGTCAGATTTCTAC-3' as a reverse primer. PCR program consisted of starting step for $5 \mathrm{~min}$ at $94^{\circ} \mathrm{C}$; then 30 cycles at $94^{\circ} \mathrm{C}$ for $30 \mathrm{~s}, 55^{\circ} \mathrm{C}$ for $30 \mathrm{~s}$, and $72^{\circ} \mathrm{C}$ for $30 \mathrm{~s}$; and a final incubation at $72^{\circ} \mathrm{C}$ for $10 \mathrm{~min}$. The DNA product of PCR was cut with Bcll restriction enzyme and separated on 3.0\% agarose gel and then analyzed under ultraviolet (UV) light. Genotypes were identified according to the following pattern: G/G genotypes gave a single 470 bp band, while A/A genotype gave two bands of $250 \mathrm{bp}$ and $220 \mathrm{bp}$.

\section{ADRB3 Trp64Arg (C/T) genotyping}

The genotyping of the ADRB3 Trp64Arg (C/T) polymorphism was determined by PCR-RFLP analysis as described before with slight modifications [22]. The
PCR was done in a final reaction volume of $20 \mu$ using primers: 5'-CGCCCAATACCGC CAACAC-3' (upstream) and 5'-CCACCAGGAGTC CCATCACC-3' (downstream), which flank the whole exon 1 of the ADRB3 gene. The PCR program consists of a starting step for 5 min at $94^{\circ} \mathrm{C}$; then 35 cycles at $94^{\circ} \mathrm{C}$ for $30 \mathrm{~s}, 61^{\circ} \mathrm{C}$ for $30 \mathrm{~s}$, and $72^{\circ} \mathrm{C}$ for $30 \mathrm{~s}$ and a final incubation step at $72^{\circ} \mathrm{C}$ by $10 \mathrm{~min}$. Then, the amplified product of PCR was cut with Mval restriction enzyme and then analyzed on a 3.0\% agarose gel, and visualized under UV light. The TT genotype gave a single band of 161 base pairs; while the CC genotype gave two bands of 99 and 62 base pairs.

\section{Clinical and laboratory data in wild type (CC) compared with CT plus TT genotypes}

Table 3 shows clinical and laboratory data (FBS, BMI, HbA1c, vegetable intake, and physical activity) in CC genotype (wild type) compared with the CT plus TT genotypes of both control and T2DM subjects. Student t-test was used to compare the numerical data while Mann-Whitney U-test was used for comparison of ordinal data.

Table 2: Genotype distribution and allele frequencies of UCP1 and ADRB3 polymorphisms in subjects with T2DM and control group

\begin{tabular}{|c|c|c|c|c|c|c|c|}
\hline \multirow{2}{*}{$\begin{array}{l}\text { UCPI } \\
\text { Polymorphism }\end{array}$} & \multicolumn{2}{|c|}{ Control $(n=110)$} & \multicolumn{2}{|c|}{ T2DM $(n=108)$} & \multirow[t]{2}{*}{$P$-value } & \multirow[t]{2}{*}{ OR } & \multirow[t]{2}{*}{$95 \% \mathrm{Cl}$} \\
\hline & $\mathrm{n}$ & $\%$ & $\mathrm{n}$ & $\%$ & & & \\
\hline \multicolumn{8}{|c|}{ UCPI polymorphism } \\
\hline \multicolumn{8}{|c|}{ Genotypes } \\
\hline AA & 56 & 50.91 & 51 & 47.22 & & 1 & \\
\hline GA & 45 & 40.91 & 43 & 39.82 & 0.886 & 1.049 & $0.597-1.845$ \\
\hline GG & 9 & 8.18 & 14 & 12.96 & 0.358 & 1.708 & $0.681-4.283$ \\
\hline \multicolumn{8}{|l|}{ Alleles } \\
\hline A & 157 & 71.36 & 145 & 67.13 & & 1 & \\
\hline G & 63 & 28.64 & 71 & 32.87 & 0.591 & 1.159 & $0.681-1.97$ \\
\hline \multicolumn{8}{|c|}{ ADRB3 polymorphism } \\
\hline \multicolumn{8}{|c|}{ Genotypes } \\
\hline CC & 84 & 76.36 & 33 & 30.56 & & 1 & \\
\hline CT & 23 & 20.91 & 71 & 65.74 & $<0.001$ & 7.85 & $4.23-14.59$ \\
\hline TT & 3 & 2.73 & 4 & 3.7 & 0.19 & 3.39 & $0.72-15.99$ \\
\hline \multicolumn{8}{|l|}{ Alleles } \\
\hline C & 191 & 86.82 & 137 & 63.43 & & 1 & \\
\hline $\mathrm{T}$ & 29 & 13.18 & 79 & 36.57 & $<0.001$ & 7.434 & $4.026-13.39$ \\
\hline
\end{tabular}

\section{Statistical analysis}

Data were analyzed using SPSS for Windows version 20.0 (SPSS Inc, Chicago. IL, USA). The analysis of the continuous variables in cases and controls was performed using Student t-test, whereas $\chi^{2}$ analysis was used to analyze the categorical data. Ordinal data were analyzed using the Mann-Whitney U-test. The difference between groups was considered statistically significant, if $p<0.05$. Odds ratios (ORs) were calculated with $95 \%$ confidence interval $(\mathrm{Cl})$.

\section{Results}

\section{Demographic, clinical, and laboratory data}

The characteristics of the studied groups are shown in Table 1. Both control and T2DM groups were 
matched for age and gender. Regarding BMI, there was no significant difference between both groups. Fasting blood sugar and HbA1c were significantly higher in subjects with T2DM compared with the control group $(P<0.001$ and $<0.05$, respectively). The vegetable intake was higher, but not significant, in control group compared with T2DM group. Furthermore, comparison of physical activity between both groups showed that the physical activity (both low and moderate activity) was higher but not significant in T2DM subjects compared with the control group while high physical activity was significantly higher in control group compared with subjects with T2DM $(P<0.001)$.

\section{UCP 1 polymorphism}

Table 2 shows the genotype and allele frequencies of the UCP1 gene polymorphism at the non-coding promoter region -3826A/G in both T2DM and control groups. The genotype distribution of UCP1 polymorphism was in Hardy-Weinberg equilibrium in both the T2DM and control groups. The genotypes AA, AG, and GG were $50.91 \%, 40.91 \%$, and $8.18 \%$, respectively, in the control group and were $47.22 \%$, $39.82 \%$, and $12.96 \%$, respectively, in T2DM group. There was no significant difference in the genotype frequency between subjects with T2DM and healthy controls $(P>0.05)$ (Table 2). The percentage of $G$ allele was $28.64 \%$ and $32.87 \%$ while $A$ allele was $71.36 \%$ and $67.13 \%$ in control and T2DM groups, respectively. There was no significant difference in the allele frequency between both T2DM subjects and healthy controls $(P>0.05)$ (Table 2). These results suggest that UCP1 A/G polymorphism at -3826 promoter region may not contribute to higher susceptibility to the T2DM in the Saudi population of Makkah region.

Table 3: Characteristics of different genotypes (CC compared with CT plus TT) of controls and subjects with T2DM

\begin{tabular}{|c|c|c|c|}
\hline \multirow[t]{2}{*}{ Characteristics } & \multicolumn{3}{|c|}{ ADRB3 (CC vs. CT plus TT) } \\
\hline & CC & CT plus TT & $P$-value \\
\hline \multicolumn{4}{|l|}{ Control } \\
\hline No & $84(76.36 \%)$ & $26(23.64)$ & \\
\hline FBS & $83.92 \pm 7.03$ & $82.54 \pm 6.96$ & NS \\
\hline BMI & $23.45 \pm 1.57$ & $23.53 \pm 1.07$ & NS \\
\hline $\mathrm{HbA} 1 \mathrm{c}(\%)$ & $4.43 \pm 1.00$ & $4.43 \pm 1.17$ & NS \\
\hline \multicolumn{4}{|c|}{ Dietary intake (Vegetable intake) } \\
\hline No or small & $58(69.05)$ & $18(69.23)$ & NS \\
\hline More & 26 (30.95) & $8(30.77)$ & NS \\
\hline \multicolumn{4}{|l|}{ Physical activity } \\
\hline Low & $31(36.90)$ & $9(34.61)$ & NS \\
\hline Moderate & $19(22.62)$ & $3(11.54)$ & NS \\
\hline High & $34(40.48)$ & $14(53.85)$ & $<0.01$ \\
\hline \multicolumn{4}{|l|}{ T2DM } \\
\hline No. & $33(30.56 \%)$ & $75(69.44 \%)$ & \\
\hline FBS & $158.95 \pm 29.8$ & $159.82 \pm 28.44$ & NS \\
\hline BMI & $23.68 \pm 1.1$ & $23.49 \pm 1.26$ & NS \\
\hline HbA1c (\%) & $7.19 \pm 1.67$ & $7.27 \pm 1.8$ & NS \\
\hline \multicolumn{4}{|c|}{ Dietary intake (Vegetable intake) } \\
\hline No or small & $27(81.82 \%)$ & $56(74.67 \%)$ & \\
\hline More & $6(18.18 \%)$ & $19(25.33 \%)$ & NS \\
\hline \multicolumn{4}{|l|}{ Physical activity } \\
\hline Low & $18(54.55 \%)$ & $39(52 \%)$ & NS \\
\hline Moderate & $11(33.33 \%)$ & $21(28 \%)$ & NS \\
\hline High & $4(12.12 \%)$ & $15(20 \%)$ & $<0.01$ \\
\hline
\end{tabular}

numerical data and Mann-Whitney U-test for ordinal data. Data are shown as mean $\pm S D$. $p<0.05$ was considered as significant. NS $=$ Non-significant. ADRB3: $\beta 3$-adrenergic receptor. T2DM: Type 2 diabetes mellitus.

\section{ADRB3 gene polymorphism}

In contrast to the data for UCP1 gene polymorphism, our results for the ADRB3 revealed a different correlation. Table 2 shows the genotype and allele frequencies of ADRB3 Trp64Arg C/T (rs4994) in studied groups. The genotype and allele distribution were all in Hardy-Weinberg equilibrium in both studied groups. The genotypes CC, CT, and TT were $76.36 \%$, $20.91 \%$, and $2.73 \%$ in control subjects, while they were $30.56 \%, 65.74 \%$, and $3.7 \%$ in subjects with T2DM, respectively. There was significant difference of CT genotypes between patients with T2DM and healthy controls and CC genotype (taken as a reference) seemed to be more protected while the CT genotypes are statistically higher in T2DM subjects compared with the controls (OR: $7.85,95 \% \mathrm{Cl}: 4.23-14.59, P<0.001)$ (Table 2). The $\mathrm{C}$ allele was $86.82 \%$ and $63.43 \%$ while $\mathrm{T}$ allele was $13.18 \%$ and $36.57 \%$ in the control and T2DM groups, respectively. The $\mathrm{C}$ allele (taken as a reference) was significantly higher in the control group than the patients with T2DM while the T allele was significantly higher in T2DM subjects compared with the control group (OR: 7.434, 95\% Cl: 4.026-13.39, $P<0.001$ ) (Table 2). This suggests that CT genotype and subjects carrying the $\mathrm{T}$ allele have higher risk for T2DM than subjects with CC genotypes who may be protected.

\section{Clinical and laboratory data in wild type} (CC) compared with CT plus TT genotypes

Table 3 shows laboratory and clinical data of the CC (wild type) and the CT plus TT genotypes of both control and T2DM subjects. There was no significant difference between CC genotype and CT plus TT genotypes in both controls and T2DM subjects regarding fasting blood sugar, $\mathrm{HbA} 1 \mathrm{c}$, vegetable intake, and physical activity (both low and moderate) with the exception of the high physical activity which was significantly higher in CT plus TT genotypes compared with CC genotype in both controls and T2DM subjects $(P<0.01)$.

\section{Discussion}

DM is a common public health problem worldwide including Saudi Arabia [4], [30]. UCP1 and ADRB3 play a pivotal role in energy expenditure in adipose tissue and the polymorphism in both genes may be associated with obesity, insulin resistance, and T2DM [8], [31]. We have investigated the gene polymorphism of both ADRB3 Trp64Arg (C/T) (rs4994) and UCP1 -3826A/G (rs1800592) and their association with the incidence of T2DM in a group of Saudi subjects. In the case of UCP1 gene, the AA genotype was found to be more common in studied Saudi subjects than GG genotype, but we did not find a significant difference 
in genotype and allele frequencies between the controls and the patients with T2DM ( $p>0.05)$. Similar results were previously obtained in several ethnic populations [13], [27], [32], [33], [34], [35]. Therefore, our results are consistent with those results. Thus, we suggested that there may be no association between UCP1 polymorphism and the incidence of T2DM among Saudi subjects. However, other investigators obtained contrary result while studying UCP1 polymorphism among Brazilians with T2DM and they observed an association between UCP1 polymorphism and the risk of T2DM among obese Brazilians [19]. These opposite results might be explained by the difference in genetic background and exposure to environmental factors such as difference in ambient temperature range in a specific region. For ADRB3, our results showed that the CC genotype was significantly higher in controls than T2DM subjects while the CT genotype and T allele were significantly higher in T2DM subjects than controls. Therefore, $\mathrm{T}$ allele may be associated with the risk of T2DM among Saudis while CC genotype and C allele may be more protected. Similar results are obtained also in a number of ethnic populations. In Mexican population, Burguete-Garcia et al suggested that the $T$ allele of ADRB3 gene can be considered an important risk factor for T2DM [31]. In Kashmiri population, it was reported that the $T$ allele of the ADRB3 gene is a genotypic risk factor to T2DM, whereas the homozygous CC genotype exerted a protective effect [36]. These results are consistent with our observation. Other investigators have obtained differing results, for example, no association was detected between Trp64Arg (C/T) polymorphism of ADRB3 gene and the risk of T2DM in a number of ethnic populations (eastern Finland, Germans, young to older Japanese men, Polish population, and Caucasian-Brazilian patients) [37], [38], [39], [40], [41]. Examination of the secondary structure of ADRB3 using computer simulations suggests that the mutant residue Arginine at 64 position of the wild type Tryptophan may reside in the critical 36-64 amino acid peptide of the protein, that is, predicted to be "buried' whereas amino acids 65-66 (computed secondary structure, data not shown) are "exposed" to the aqueous side. This is followed by amino acid 67, that is, "buried," and amino acids 68, 69 are "exposed" and a sequence of 31 residues $70-100$ are "buried." Thus, helical transmembrane region 38-63 may be sensitive to a change from a highly hydrophobic tryptophan to highly charged polar amino acid Arginine (unpublished data of ADRB3 structural analysis). Since protein mobility in the membrane is related to changes in the temperature, environmental ambient temperature and energy metabolism may mediate receptor activity differently for the Arginine mutant Trp64Arg of the ADRB3.

The discrepancy between the above results and our observations may, among other possibilities, be clarified by differences in the genetic background of the participants or because of some intriguing environmental factors, such as temperature variations, may be physiologically important. One factor for consideration in our results on UCP1 and ADRB3 gene polymorphisms is that, this research has been made in Makkah environs of Saudi Arabia, an area that is known to have two seasonal variations, hot, and extremely hot. This is unlike many European nations, North America, and even areas in Asian countries that are situated in the northern hemisphere, and have significant cold seasons in addition to the hot and milder spells of temperature changes.

The limitation in this study is the small number of studied subjects. Further studies will be needed in a large T2DM cohort with clinical data to understand the role of UCP1 and ADRB3 gene polymorphisms in the pathogenesis of T2DM.

\section{Conclusion}

Our data showed that the UCP1 $-3826 \mathrm{~A} / \mathrm{G}$ polymorphism in the promoter region did not result in statistically significant susceptibility to T2DM among Saudi population in Makkah region. In contrast, the T allele of ADRB3 gene polymorphism may be associated with the increased risk of T2DM. Interestingly, the CC genotypes in the ADRB3 gene appear to be more protective. Since genetic diversity plays a critical role in physiological outcome and phenotypes, it is important to note that genetic polymorphism studies may vary with different ethnic and environmental conditions.

\section{Acknowledgment}

The authors thank Dr. Abdulrahman Yousuf for his technical support in the research laboratory in Faculty of Dentistry, Um Al-Qura University, Saudi Arabia. Also, the authors thank Dr. Abdelaziz Yaseen for his help and support in the statistics section.

\section{References}

1. Kopelman PG. Obesity as a medical problem. Nature. 2000;404(6778):635-43. https://doi.org/10.1038/35007508 PMid:10766250

2. Eckel RH, Grundy SM, Zimmet PZ. The metabolic syndrome Lancet. 2005;365(9468):1415-28. https://doi.org/10.1016/ S0140-6736(05)66378-7

PMid:15836891

3. Elhadd T, Al-Amoudi A, Alzahrani A. Epidemiology, clinica 
and complications profile of diabetes in Saudi Arabia: A review. Ann Saudi Med. 2007;27(4):241-50. https://doi. org/10.5144/0256-4947.2007.241

\section{PMid: 17684435}

4. Robert AA, Al Dawish MA, Braham R, Musallam MA, Al Hayek A, Al Kahtany NH. Type 2 diabetes mellitus in Saudi Arabia: Major challenges and possible solutions. Curr Diabetes Rev. 2017;13(1):59-64. https://doi.org/10.2174/1573399812666 160126142605

PMid:26813972

5. Diabetes Prevention Program (DPP) Research Group. The diabetes prevention program (DPP): Description of lifestyle intervention. Diabetes Care. 2002;25(12):2165-71. https://doi. org/10.2337/diacare.25.12.2165

PMid:12453955

6. Lindström J, Louheranta A, Mannelin M, Rastas M, Salminen V, Eriksson J, et al. The Finnish diabetes prevention study (DPS): Lifestyle intervention and 3-year results on diet and physical activity. Diabetes Care. 2003;26(12):3230-6. https://doi. org/10.2337/diacare.26.12.3230

PMid: 14633807

7. Gillies CL, Abrams KR, Lambert PC, Cooper NJ, Sutton AJ, Hsu RT, et al. Pharmacological and lifestyle interventions to prevent or delay Type 2 diabetes in people with impaired glucose tolerance: Systematic review and meta-analysis. BMJ. 2007;334(7588):299. https://doi.org/10.1136/ bmj.39063.689375.55

PMid:17237299

8. Brondani LA, Assmann TS, Duarte GC, Gross JL, Canani LH, Crispim D. The role of the uncoupling protein 1 (UCP1) on the development of obesity and Type 2 diabetes mellitus. Arq Bras Endocrinol Metabol. 2012;56(4):215-25. https://doi.org/10.1590/ s0004-27302012000400001

PMid:22790465

9. Ryuk JA, Zhang X, Ko BS. Association of $\beta 3$-adrenergic receptor rs4994 polymorphisms with the risk of Type 2 diabetes: A systematic review and meta-analysis. Diabetes Res Clin Pract. 2017;129:86-96. https://doi.org/10.1016/j.diabres.2017.03.034 PMid:28521197

10. Babol K, Błasiak J. Beta3-adrenergic receptor. Postepy Biochem. 2005;51(1):80-7.

PMid:16209345

11. Cioffi F, Senese R, de Lange P, Goglia F, Lanni A, Lombardi A. Uncoupling proteins: A complex journey to function discovery. Biofactors. 2009;35(5):417-28. https://doi.org/10.1002/biof.54 PMid:19626697

12. Jia JJ, Tian YB, Cao ZH, Tao LL, Zhang X, Gao SZ, et al. The polymorphisms of UCP1 genes associated with fat metabolism, obesity and diabetes. Mol Biol Rep. 2010;37(3):1513-22. https:// doi.org/10.1007/s11033-009-9550-2

PMid: 19444646

13. de Souza BM, Brondani LA, Bouças AP, Sortica DA, Kramer CK, Canani LH, et al. Associations between UCP1-3826A/G, UCP2866G/A, Ala55Val and Ins/Del, and UCP3 -55C/T polymorphisms and susceptibility to Type 2 diabetes mellitus: Case-control study and meta-analysis. PLoS One. 2013;8:e54259. https:// doi.org/10.1371/journal.pone.0054259

14. Collins $\mathrm{S}$, Yehuda-Shnaidman $\mathrm{E}$, Wang $\mathrm{H}$. Positive and negative control of Ucp1gene transcription and the role of $\beta$-adrenergic signaling networks. Int J Obes. 2010;34(1):S28-33. https://doi. org/10.1038/ijo.2010.180 PMid:20935662

15. Richard D, Picard F. Brown fat biology and thermogenesis. Front Biosci (Landmark Ed). 2011:16:1233-60. https://doi. org/10.2741/3786
PMid:21196229

16. Bertholet AM, Kirichok Y. UCP1: A transporter for $\mathrm{H}^{+}$and fatty acid anions. Biochimie. 2017;134:28-34. https://doi. org/10.1016/j.biochi.2016.10.013

PMid:27984203

17. Nakano $T$, Shinka $T$, Sei $M$, Sato $Y$, Umeno $M$, Sakamoto $K$, et al. A/G heterozygote of the A-3826G polymorphism in the UCP-1 gene has higher BMI than A/A and G/G homozygote in young Japanese males. J Med Invest. 2006;53(3-4):218-22. https://doi.org/10.2152/jmi.53.218

PMid: 16953057

18. Hamada T, Kotani K, Nagai N, Tsuzaki K, Matsuoka Y, Sano $Y$, et al. Low-calorie diet-induced reduction in serum HDL cholesterol is ameliorated in obese women with the-3826 G allele in the uncoupling protein-1 gene. Tohoku J Exp Med. 2009;219(4):337-42. https://doi.org/10.1620/tjem.219.337

19. Nicoletti $C F$, de Oliveira AP, Brochado MJ, de Oliveira BP, Pinhel MA, Marchini JS, et al. UCP1-3826 A>G polymorphism affects weight, fat mass, and risk of Type 2 diabetes mellitus in grade III obese patients. Nutrition. 2016;32(1):83-7. https://doi. org/10.1016/j.nut.2015.07.016

PMid:26458326

20. Gagnon J, Mauriège $P$, Roy $S$, Sjöström $D$, Chagnon $Y C$ Dionne FT, et al. The Trp64Arg mutation of the $\beta 3$ adrenergic receptor gene has no effect on obesity phenotypes in the Québec family study and Swedish obese subjects cohorts. J Clin Invest. 1996;98(9):2086-93. https://doi.org/10.1172/JCl119014 PMid:8903328

21. Walston J, Silver K, Bogardus C, Knowler YC, Celi SF, Austin S, et al. Time of onset of non-insulin-dependent diabetes mellitus and genetic variation in the $\beta 3$-adrenergic receptor gene. N Engl J Med. 1995;333(6):343-7. https://doi.org/10.1056/ NEJM199508103330603 PMid:7609750

22. Widén $E$, Lehto $M$, Kanninen $T$, Walston J, Shuldiner $A R$, Groop LC. Association of a polymorphism in the beta 3 -adrenergic receptor gene with features of the insulin resistance syndrome in Finns. N Engl J Med. 1995;333(6):348-51. https:// doi.org/10.1056/NEJM199508103330604 PMid:7609751

23. Clément K, Vaisse C, Manning BS, Basdevant A, Guy-Grand B, Ruiz J, et al. Genetic variation in the beta 3-adrenergic receptor and an increased capacity to gain weight in patients with morbid obesity. N Engl J Med. 1995;333(6):352-4. https://doi. org/10.1056/NEJM199508103330605 PMid:7609752

24. Kadowaki H, Yasuda K, Iwamoto K, Otabe S, Shimokawa K, Silver $\mathrm{K}$, et al. A mutation in the beta 3-adrenergic receptor gene is associated with obesity and hyperinsulinemia in Japanese subjects. Biochem Biophys Res Commun. 1995;215(2):555-60. https://doi.org/10.1006/bbrc.1995.2500 PMid:7487991

25. Morita E, Taniguchi H, Sakaue M. Trp64Arg polymorphism in beta3-adrenergic receptor gene is associated with decreased fat oxidation both in resting and aerobic exercise in the Japanese male. Exp Diabetes Res. 2009;2009:605139. https:// doi.org/10.1155/2009/605139

PMid:20069060

26. Valve $R$, Heikkinen $S$, Rissanen $A$, Laakso $M$, Uusitupa $M$ Synergistic effect of polymorphisms in uncoupling protein 1 and beta3-adrenergic receptor genes on basal metabolic rate in obese Finns. Diabetologia. 1998;41(3):357-61. https://doi. org/10.1007/s001250050915 PMid:9541178

27. Sivenius K, Valve R, Lindi V, Niskanen L, Laakso M, Uusitupa M. 
Synergistic effect of polymorphisms in uncoupling Protein 1 and beta3-adrenergic receptor genes on long term body weight change in Finnish Type 2 diabetic and non-diabetic control subjects. Int J Obes Relat Metab Disord. 2000;24(4):514-9. https://doi.org/10.1038/sj.ijo.0801194

PMid:10805511

28. Shihara N, Yasuda K, Moritani T, Ue H, Uno M, Adachi T, et al Synergistic effect of polymorphisms of uncoupling protein 1 and beta3-adrenergic receptor genes on autonomic nervous system activity. Int J Obes Relat Metab Disord. 2001;25(6):761-6. https://doi.org/10.1038/sj.ijo.0801629

PMid:11439286

29. Cassard-Doulcier AM, Bouillaud F, Chagnon M, Gelly C, Dionne FT, Oppert JM, et al. The Bcl I polymorphism of the human uncoupling protein (ucp) gene is due to a point mutation in the 5'-flanking region. Int $\mathrm{J}$ Obes Relat Metab Disord. 1996;20(3):278-9.

PMid:8653151

30. Al Dawish MA, Robert AA, Braham R, Al Hayek AA, Al Saeed A, Ahmed RA, et al. Diabetes mellitus in Saudi Arabia: A review of the recent literature. Curr Diabetes Rev. 2016;12(4):359-68. https://doi.org/10.2174/1573399811666150724095130 PMid:26206092

31. Burguete-Garcia AI, Martinez-Nava GA, Valladares-Salgado A, Morales VH, Estrada-Velasco B, Wacher N, et al. Association of $\beta 1$ and $\beta 3$ adrenergic receptors gene polymorphisms with insulin resistance and high lipid profiles related to Type 2 diabetes and metabolic syndrome. Nutr Hosp. 2014;29(6):1327-34. PMid:24972470

32. Boullu-Sanchis $S$, Leprêtre F, Hedelin G, Donnet JP, Schaffer P, Froguel P, et al. Type 2 diabetes mellitus: Association study of five candidate genes in an Indian population of Guadeloupe, genetic contribution of FABP2 polymorphism. Diabetes Metab. 1999;25(2):150-6.

PMid:10443326

33. Schäffler A, Palitzsch KD, Watzlawek E, Drobnik W, Schwer H, Schölmerich $\mathrm{J}$, et al. Frequency and significance of the A-->G $(-3826)$ polymorphism in the promoter of the gene for uncoupling protein-1 with regard to metabolic parameters and adipocyte transcription factor binding in a large populationbased Caucasian cohort. Eur J Clin Invest. 1999;29(9):770-9. https://doi.org/10.1046/j.1365-2362.1999.00529.x PMid:10469165

34. Vimaleswaran KS, Radha V, Ghosh S, Majumder PP, Rao MR, Mohan V. A haplotype at the UCP1 gene locus contributes to genetic risk for Type 2 diabetes in Asian Indians (CURES-72). Metab Syndr Relat Disord. 2010;8(1):63-8. https://doi. org/10.1089/met.2009.0039

\section{PMid:19943796}

35. Ramos AV, Bastos-Rodrigues L, Resende BA, Friedman E, Campanha-Versiani L, Miranda DM, et al. The contribution of FTO and UCP 1 SNPs to extreme obesity, diabetes and cardiovascular risk in Brazilian individuals. BMC Med Genet. 2012;13:101. https://doi.org/10.1186/1471-2350-13-101

PMid:23134754

36. Hameed I, Masoodi SR, Afroze D, Naykoo NA, Bhat RA Ganai BA. Trp homozygotes at codon 64 of ADRB3 gene are protected against the risk of Type 2 diabetes in the Kashmiri population. Genet Test Mol Biomarkers. 2013;17(10):775-9. https://doi.org/10.1089/gtmb.2013.0297

PMid:23968135

37. Rissanen J, Kuopusjärvi J, Pihlajamäki J, Sipiläinen $R$, Heikkinen S, Vanhala M, et al. The Trp64Arg polymorphism of the beta 3-adrenergic receptor gene. Lack of association with NIDDM and features of insulin resistance syndrome. Diabetes Care. 1997;20(8):1319-23. https://doi.org/10.2337/ diacare.20.8.1319 PMid:9250462

38. Büettner R, Schäffler A, Arndt H, Rogler G, Nusser J, Zietz B, et al. The Trp64Arg polymorphism of the beta 3-adrenergic receptor gene is not associated with obesity or Type 2 diabetes mellitus in a large population-based Caucasian cohort. J Clin Endocrinol Metab. 1998;83(8):2892-7. https://doi.org/10.1210/ jcem.83.8.5004

PMid:9709965

39. Ishii T, Hirose H, Kawai T, Hayashi K, Maruyama H, Saito I, et al. Effects of intestinal fatty acid-binding protein gene Ala54Thr polymorphism and beta3-adrenergic receptor gene Trp64Arg polymorphism on insulin resistance and fasting plasma glucose in young to older Japanese men. Metabolism. 2001;50(11):13017. https://doi.org/10.1053/meta.2001.27228

\section{PMid:11699048}

40. Kasznicki J, Blasiak J, Majsterek I, Przybyłowska K, Drzewoski J The Trp64Arg beta3-adrenergic receptor amino-acid variant is not associated with overweight and Type 2 diabetes mellitus in Polish population. Exp Clin Endocrinol Diabetes. 2005;113(10):593-7. https://doi.org/10.1055/s-2005-872840 PMid:16320158

41. Brondani LA, Duarte GC, Canani LH, Crispim D. The presence of at least three alleles of the ADRB3 $\operatorname{Trp} 64 \operatorname{Arg}(\mathrm{C} / \mathrm{T})$ and UCP1-3826A/G polymorphisms is associated with protection to overweight/obesity and with higher high-density lipoprotein cholesterol levels in Caucasian-Brazilian patients with Type 2 diabetes. Metab Syndr Relat Disord. 2014;12(1):16-24. https:// doi.org/10.1089/met.2013.0077

PMid:24138564 